\title{
The Impact of Fiscal and Monetary Policy Changes on Investors' Investment Performance: Empirical Evidence from Investors in the Colombo Stock Exchange in Sri Lanka
}

\author{
Menike, L. M. C. S. \\ Department of Accountancy and Finance, Faculty of Management Studies, Sabaragamuwa \\ University of Sri Lanka, P.O.Box 02, Belihuloya, Sri Lanka \\ suba@mgt.sab.ac.1k
}

\begin{abstract}
The effect of fiscal and monetary policy is transmitted in several ways by investor choice and the performance of investments. This study investigates how individual investors perceive government fiscal and monetary policy decisions and how they respond to such policy changes to make profitable investments. The data were gathered from a diversified group of 364 individual investors in the Colombo Stock Exchange (CSE) by administering a structured questionnaire focusing on their opinions of fiscal and monetary policy changes. Factor analysis was carried out to identify the meaningful fiscal and monetary policy actions that determine individual investment decisions and performance. The results of multiple regression analysis show that the government's choice of tax instruments has a significant influence on stock returns and all taxes jointly depress investor investment performance. Government expenditure as a fiscal policy variable has a positive impact on investor returns, implying that a continual increase in government expenditure will result in the enhancement of firm profits and returns to investors by allowing stock prices to go up. Thus, market participants might assume that expansionary fiscal policy signals an increase in future returns. Further, a decline in interest rates and an increase in money circulation under monetary policy impacts positively on investors' investment performance. As expected, an increase in money circulation in the economy will persuade investors to invest more in stocks as extra funds are available. These results have important implications for both investors and stock market analysts in their effort to understand the impact of fiscal and monetary policies on the stock return expectations of individual investors, but they should consider both fiscal and monetary policy decisions and their interactions together rather than in isolation.
\end{abstract}

Keywords: Colombo Stock Exchange, Fiscal Policy, Individual Investors, Investment Performance, Monetary Policy

\section{Introduction}

Budget and current account deficits are important features of Sri Lanka's economy. The country has been experiencing a growing fiscal deficit along with a current account deficit since the 1960s. Despite the above deficits the country has shown a remarkable improvement in the other key macroeconomic variables, especially during the aftermath of the recent civil war. However, the country is vulnerable to both internal and external shocks and it is more difficult to select appropriate and more powerful fiscal and monetary policies to reduce economic distortions to obtain sustainable growth. Rather, the prolonged fiscal expansions contribute to the current account imbalances and cause macroeconomic instability. Theoretically, fiscal policy actions (changes in expenditure or taxes) and monetary policy actions (interest rate and money supply) play a significant role in the behaviour of investors and on the performance of the stock market. Therefore, a change in either fiscal or monetary policy instruments leads to a change in interest rates immediately and thus investors revalue their equity stocks and readjust their portfolios, as a contractionary or expansionary fiscal and monetary policy would have either positive or unfavorable effects on the returns of investors. Further, the value of their wealth, provided by the sum of discounted future cash flows, is affected by an easing or tightening of monetary policy through the discount rate. Ultimately, fiscal expansion leads to higher interest rates and a weakening of economic activity, resulting in further deterioration of the fiscal and current account imbalances that can trigger economic instability [Laopodis, 2006]. 
In recent years, an increasing number of studies have observed the effects of monetary policy on stock markets [Bjornland \& Leitemo, 2009, Gali \& Gertler, 20007], while few have explored the effects of fiscal policy on stock markets [Afonso \& Sousa, 2011, Jansen et al., 2008] others have investigated the effects of monetary and fiscal policy on the stock market when the two policies interact [Chatziantoniou et al., 2013, Jansen et al., 2008]. It is widely accepted that monetary policy should not be examined in isolation from fiscal policy, and vice versa, as both their individual stances, as well as their interaction, play an important role in the economy and they also influence stock market performance [Chatziantoniou et al., 2013]. Lawal et al. (2018) suggest calibrating both monetary and fiscal policies in a single model when formulating stock market policy as their interaction exerts significant pressure on stock market behaviour, thus both policies should be considered in tandem. Nwaogwugwu (2018) finds that money supply and interest rate and government spending and taxation have significant effects on the stock market in the short and long run.

Ehrmann \& Fratzscher (2004), Rigobon \& Sack (2003), and Sousa (2010) explain that there is a negative relationship between contractionary monetary policy and stock market performance. Alternatively, monetary policy decisions affect stock prices not only through trade-offs between interest gains and stock returns, but also through their influence on investor expectations, and Gali \& Gertler (2007), Bjornland \& Jacobsen (2008), Bjornland \& Leitemo (2009), Kurov (2010) and Castelnuovo \& Nistico (2010) show that stock prices are mainly forward looking and include relevant information regarding expectations about the future in which monetary policy innovations can greatly affect those expectations. Some studies suggest that there exists a strong negative relationship between monetary policy innovations and stock market performance in the United States. Among others Poole \& Rasche (2000), Kuttner (2001), Bomfim (2003), and Bernanke \& Kuttner (2005) confirm that monetary policy decisions may have an influence on financial markets in many ways; through their effects on real interest rates, expected future dividends and expected future stock returns.

It is evident that there has been research work on the impact of fiscal policy on stock market performance. Darrat (1988) suggests that the fiscal deficit exerts a highly significant negative effect on current stock prices. Agnello \& Sousa (2011) find that there is an immediate temporary negative response of stock prices to fiscal policy shocks, whereas Afonso \& Sousa (2011) emphasize government revenue and expenditure separately and report that government expenditure shocks have a negative effect on stock prices and government revenue shocks have little positive effects on stock prices. Further, Van Aarle et al. (2003) and Laopodis (2010) confirm that fiscal policy is important in determining stock prices. The available literature on this matter thus depicts mixed results as some researchers find strong impact of fiscal policy on stock market performance while others conclude that it is weak [Jakova, 2016, Muyanga, 2014, Tavares \& Valkanov, 2003, Trebicka, 2015]. Fiscal policy plays a vital role in the determination of stock and bond returns. Here, Tavares \& Valkanov (2003) find that the influence of fiscal policy on financial markets can be direct or indirect.

Investors are generally more sensitive to fiscal and monetary policy changes and investigating the behaviour of investors in response to fiscal and monetary policy news announcements is an important aspect which is missing in the literature in the Sri Lankan context. It will be beneficial to the country to eliminate the negative influence of persistent negative budget and current account balances on investment performance thereby bringing the country to a faster growth path.

This study provides a significant contribution to the field of finance by identifying the stock market as an important channel for transmitting the impact of fiscal and monetary policy. Although the impact of monetary and fiscal policy on the stock market has been widely analysed this study is the first to examine the effect of fiscal and monetary policy jointly on individual investor performance using survey data. This approach offers information on how individual investors perceive government fiscal and monetary policy decisions and how they respond to such policy changes to make profitable investments. For instance, market participants react positively to a decreasing interest rate if companies can offer increasing returns to their investors. Investors view growing government expenditure and tax cuts as good news for their investment performance and 
act accordingly to achieve higher returns. Investors show that they tend to make investment strategies if excess money is available because of increased money circulation. Thus, this work enriches the body of knowledge by investigating how individual investors react to expansionary and contractionary fiscal and monetary policies that are aimed at achieving growth in real activity, the exchange rate, price stability, and the balance of payment equilibrium and employment.

The paper is structured as follows. Section 2 presents the literature review and section 3 outlines the methodological approach while results and discussions of the impact of fiscal and monetary policy actions on individual investors' behaviour are presented in Section 4. Section 5 offers our concluding remarks.

\section{Fiscal and Monetary Policy and the Stock Market}

In recent years, the literature investigating the relationship between monetary policy and stock market performance in the developed as well as the developing countries has been growing. The theoretical framework through which monetary policy influences the behaviour of the stock market has five channels: interest rate channel; credit channel; wealth effect channel; exchange rate channel; and Tobin's Q investment hypothesis [Mishkin, 2001].

The interest rate channel that is based on the traditional Keynesian hypothesis of the transmission mechanism of interest rates explains that fluctuations in interest rates will impact on firms' corporate cost of capital, thereby altering the present value of future net cash flows and leading to lower stock prices. The credit channel implies an indirect monetary policy transmission of interest rate adjustments through which the monetary authority influences the level of investment which will alter the market value of firms that in turn influence the present values of its future cash flows. The wealth effect provides a transmission mechanism for monetary policy influences on stock market performance and how such an increase in interest rates will lead to a fall in stock prices.

The exchange rate channel explains the way in which interest rates may influence stock prices through higher interest rates that lead to an appreciation of the domestic exchange rate, resulting in higher imports and lower exports.
Here, lower exports have a negative effect on the competitiveness of the country, leading to a reduction in production and to lower asset prices. Finally, the Tobin's Q theory of investment observed that higher interest rates will lead to lower asset valuations thereby shifting funds from stocks to bonds (assuming that only these two assets exist in the market) and causing stock prices to fall [Chatziantoniou et al., 2013].

Monetary Policy and Stock Market: Stock prices react in multidimensional ways to monetary policy decisions and in recent years an increasing number of studies have observed the effects of monetary policy on stock markets. Recently, Ehrmann \& Fratzscher (2004), Rigobon \& Sack (2003), and Sousa (2010) have explained that there is a negative relationship between contractionary monetary policy and stock market performance. Alternatively, monetary policy decisions affect stock prices not only through the trade-off between interest gains and stock returns, but also through their influence on investors' expectations. Gali \& Gertler (2007), Bjornland \& Jacobsen (2008), Bjornland \& Leitemo (2009), Kurov (2010), and Castelnuovo \& Nistico (2010) show that stock prices are mainly forward looking and include relevant information regarding expectations about the future and monetary policy innovations can greatly affect these expectations. Rigobon \& Sack (2003) and Bjornland \& Leitemo (2009) argue that a reverse positive causation runs from the stock market to monetary policy in the presence of readily available information incorporated in financial markets.

A few studies suggest that there exists a strong negative relationship between monetary policy innovation and stock market performance in the United States. Among others Poole \& Rasche (2000), Kuttner (2001), Bomfim (2003), and Bernanke \& Kuttner (2005), confirm that monetary policy decisions may have an influence on financial markets in many ways; through their effects on real interest rates, expected future dividends and expected future stock returns. Bredin et al. (2007) support the view that the changes in the UK policy rate negatively impact on FTSE returns. Francesco (2008) argues that expansive monetary policy may influence stock market returns much more than restrictive monetary policy, whereas Gregoriou et al. (2009) suggest that expansionary monetary policy has 
not been able to reverse the downward negative trend in stock returns and that the stock market response to expected and unexpected interest rates is negative during credit crises. Okpara (2010) investigates the effect of monetary policy on stock market returns in Nigeria and finds that monetary policy is a significant determinant of long run stock market returns whereas high Treasury bill rates reduce stock market returns.

Osamuonyi \& Evbayiro-Osagie (2012) attempt to determine the relationship between money supply and the Nigerian capital market index using yearly data on interest rates, inflation rates, exchange rates, fiscal deficit, GDP and money supply by employing a Vector Error Correction Model. The results reveal that money supply has a significant but negative relationship with the Stock Market Index in both the short- run and long run. Naik (2013) examines the relationships between the Indian stock market index (BSE Sensex) and five macroeconomic variables, namely the industrial production index, the wholesale price index, the money supply, treasury bill rates, and exchange rates over the period 1994-2011. Johansen's cointegration and vector error correction model (VECM) analysis shows that in the long-run stock prices are positively related to the money supply (M3) and that the money supply affects stock prices only in the long-run. However, no causality from stock price to money supply is found either in the long run or in the short run. This may be because money supply changes have an indirect effect through their effect on real output, which in turn impacts on stock prices.

Fiscal Policy and the Stock Market: Theoretically, the impact of fiscal policy on the stock market may either be positive, negative or insignificant based on whether one takes a Keynesian, a Neo-classical or a Ricardian view. The Keynesian model states that an increase in government expenditure leads to higher economic growth, which implies that it boosts domestic output and fuels the growth of the economy, thereby potentially increasing stock prices. In contrast, the Ricardian view requires that policy can have no impact on aggregate demand as any public borrowing will be offset by the private savings of rational households. Alternatively, classical economic theory argues about the crowding-out effects of fiscal policy in the market for loanable funds and in the productive sectors of the economy.
Thus, fiscal policy could drive stock prices lower through the crowding out of private sector activity.

Empirically, to better understand the effects of fiscal policy on the stock market a few authors have emphasized the key role of the financial market on the real and financial parts of the economy [Blanchard, 1981, Shah, 1984, Tobin, 1969]. Tobin (1969) gives emphasis to the role of fiscal policy on stock markets, focusing on its effects on interest rates and the confidence effects of long-run sustainability in the budgetary position. Empirically, there have been a few studies on the impact of fiscal policy on stock market performance and Darrat (1988) suggests that the fiscal deficit exerts a highly significant negative effect on current stock prices. Agnello \& Sousa (2011) find that there is an immediate temporary negative response of stock prices to fiscal policy shocks, whereas Afonso \& Sousa (2011) emphasize government revenue and expenditure separately and report that government expenditure shocks have a negative effect on stock prices while government revenue shocks have little positive effect on stock prices. Further, Van Aarle et al. (2003) and Laopodis (2010) confirm that fiscal policy is important for determining stock prices.

Arin et al. (2009) investigate the effects of various tax policy innovations on stock market returns in G3 countries - the United States, Japan and Germany- and their findings reveal that indirect taxes have a larger effect on market returns than labour taxes. Further, corporate tax innovations do not have any statistically significant effect on stock returns. This finding is dependent on a firm's ability to swing between equity financing and bond financing.

Using a flexible semi-parametric varying coefficient model specification, Jansen et al. (2008) examine the role of fiscal policy on US asset markets (stocks, corporate and treasury bonds) by considering two possible roles of fiscal deficits (or surpluses): the first as a separate direct information variable and the second as a conditioning information variable indicating binding constraints on monetary policy actions. The results show that the impact of monetary policy on the stock market varies depending on fiscal expansion or contraction and the impact of fiscal policy on corporate and Treasury Bond yields follow similar patterns to that of the equity market. The results are consistent with the indication of strong 
inter-dependence between monetary and fiscal policies and the increase in public debt accelerated by financial crises has raised uncertainty about future tax pressures and economic activities. Alternatively, Ardagna (2009) shows that fiscal adjustments based on expenditure reductions are related to an increase in stock market prices.

Using fiscal and monetary theories to examine the effects of fiscal policies on the strength of capital markets, G'ond'or \& Bresfelean (2011) argue that far from being a factor with small influence, fiscal policy is a major factor that can influence markets, with this influence reflected in the behaviour of all factors mentioned as important for market capital strengths - interest rates, inflation rates and exchange rates. Similarly, Goodness et al. (2012) study fiscal policy shocks and the dynamics of asset prices in South Africa and find that deficit spending shock does not affect house prices but temporarily exerts positive effects on stock prices, that fiscal policy shock affects stock prices in the short run, that monetary policy exerts a more direct effect on asset markets, and that contractionary monetary policy shocks lower real stock prices.

\section{Fiscal and monetary policy interactions and the stock market}

In the empirical literature, a few scholars argue that though both fiscal and monetary policy have become important independent policy determinants of stock prices, their impact can also be influenced by the two policies' interactions. Sargent \& Wallace (1981) explain that the implementation of tight monetary policy eventually means higher inflation when the interest rate is greater than the growth rate of the economy. Further implications of an unsustainable fiscal policy can be seen in the capital outflows and currency depreciation that are a result of increased default probability and sovereign risk premium. This causes an additional debt burden to the country and creates a vicious cycle of inflationary pressures, which will in turn necessitate increasing interest rates [Zoli, 2005]. Melitz (1997) finds that monetary and fiscal policies tend to move in opposite directions after investigating the coordination and interaction of fiscal and monetary authorities appraisals on how they work in practice. Muscatelli \& Tirelli (2005) and Zoli (2005) reveal that the two demand-side policies interact through the impact of government inter-temporal budget constraints on monetary policy and the effect of fiscal policy on monetary variables, namely, inflation, interest and exchange rates. The inter-temporal budget constraint necessitates that government expenditure is financed through taxation /borrowing.

In a subsequent paper Melitz (2000) explains this finding as the tightening (easing) of one instrument means less tightening (easing) of the other and both instruments may still concurrently be tight (or easy as the case may be). Afonso\& Sousa (2011) state that it is important to allow for the interaction of both policies when assessing their impact on stock prices, while Van Aarle et al. (2003) highlight the importance of integrating monetary and fiscal policies within one framework in which the interactions and effects of both can be analysed. Ioannis, David and Georgeet (2011) observe the stock market response to monetary and fiscal policy shocks using quarterly data and find that both fiscal and monetary policies influence stock market returns through direct and indirect channels and that the interaction between the two policies is vital in explaining stock market development. Thus, both fiscal and monetary policies should be considered together rather than taken in isolation. Chatziantoniou et al. (2013) investigate the effects of monetary and fiscal policy shocks on the stock market performance in Germany, the UK, and the USA and show that both fiscal and monetary policies influence the stock market through direct or indirect channels. Notably, they report that the interaction between the two policies is vital in explaining stock market developments.

The extant literature reveals that there are many studies that focus on the impact of fiscal and monetary policy on stock market performance in both developed and developing countries. However, it is exceedingly rare to find studies that investigate investor opinions on the influence government fiscal and monetary policy changes on individual investor performance. This study attempts to observe how individual investors respond to fiscal and monetary policy actions to achieve better returns. Further, the above critical review of the literature highlights that the findings vary from one study to another and between countries as per the methodology used, countries examined, sample period used and country specific events such as the size of the stock market and regulations, political situation and 
investor participation including foreign investors. Thus, this study provides a unique opportunity to investigate a new aspect of how individual investors make decisions with respect to fiscal and monetary policy changes.

\section{Methods}

The study investigates the perceptions of individual investors that might be influenced by their psychology. This stems from individuals and we aim to identify which fiscal and monetary policy news/events they consider as being of utmost importance to them to ascertain higher returns in making portfolio diversification strategies. The deductive approach is utilized to study the research problem and the data acquisition method is quantitative. The unit of analysis is individual investors in CSE and it is worthwhile to select a representative sample from the entire active investors group as they are the people who search for a variety of information in making their trading decisions. It was not practical to investigate the entire population of individual investors and the study concentrated only on the active investors. 364 clients were selected from among these investors using stratified random sampling based on the particulars given by seven leading brokerage firms. Primary data was obtained from the investors themselves as they queued to be served in their respective brokerage firms and on the CSE trading floor, resulting in a higher response rate. Those respondents who faced any difficulty in filling out the questionnaire were guided by a research assistant who was also responsible for administering and collecting the questionnaires.

This study observes how individual investors perceive news on fiscal and monetary policies on their investment decisions and performance in the CSE using an individual survey method. Proper care has been taken to ensure that the facts match with the objectives, and this is in line with the data collected through the questionnaire. Moreover, attention was paid to designing the questionnaire using simple and clear words, and ensuring the logical and sequential arrangement of questions with regards to the government policy changes on fiscal and monetary policies. Thus, the entire questionnaire is based on numerous future scenarios on the above policy changes and asked respondents for their level of agreement.
The questionnaire was structured into six sections: Demographic Factors, Government Fiscal Policy Decisions, State Monetary Policy Decisions, Balance of Payments, and Investment Performance. Section I sought to capture general data about the investor and his/her age, gender, marital status, education, monthly income, portfolio value, years of experience in the stock market, and the most preferred sectors to invest in the stock market. Section II covers government fiscal policy decisions such as revenue and includes four questions relating to tax policies (income tax, corporate tax, withholding tax, the introduction of various income tax concessions encouraging exporters, and making an investment friendly environment which highly influence investors investment decisions and performance), government expenditure that contains four items (increased government expenditure as measured by the rapid development of infrastructure facilities, an increase in the defense budget, a substantial increase in expenditure on public administration and service and an increase in salaries and wages of public servants), and deficit financing that includes another three items with regard to the means of financing the budget deficit (increases in interest rate as a result of borrowings from the banking sector to finance the budget deficit, an increase in the inflow of foreign aid and the higher tendency of government towards privatization).

Section III is devoted to government monetary policy actions and contains five questions to represent the interest rate, the treasury bill rate, money circulation in the community, and financial sector consolidation (government keeping the interest rate low, the low treasury bills yield rate, increasing the amount of money circulated among the public as a result of disbursement of credits by commercial banks in the form of loans at low interest rates, and launching government special loan schemes aimed at enhancing investment and consolidation in the financial sector with the aim of building a strong, dynamic and internationally competitive financial sector). Section IV covers four items - the exchange rate, BOP deficit, FDI, FPI, and Tariffs.

The last section corresponds to investment performance of individual investors covering the recent return rate of their investments and their satisfaction on their investment decisions. For all the above sections (except Section I) the 
respondents were asked to indicate the degree of influence of each of the items on five-point Likert scale. The 5 points in the scale are respectively from 1 to 5: extremely disagree, disagree, neutral, agree and extremely agree. The drafts of the questionnaire were tested by two academics, two investor advisors and two high net worth individual investors. To defend the validity and reliability of the questionnaire a pilot survey was conducted before the main survey and this verified whether the questions are understandable; whether the instructions are clear, the order of the questions is appropriate, and that the questions are meaningful.

Table 1: KMO and Bartlett's Test

\begin{tabular}{llr}
\hline \multicolumn{2}{c}{ Kaiser-Meyer-Olkin Measure of } & 0.821 \\
Sampling Adequacy & \\
Bartlett's Test of & Approx. $\chi^{2}$ & 978.626 \\
Sphericity & df & 190 \\
& Sig. & 0.000 \\
\hline
\end{tabular}

The collected data were processed and analyzed by using Minitab software. Firstly, the data were cleaned by eliminating the questionnaires that had too many missing values or bias ratings. Next, the reliability of each construct and its precise dimensions were judged using Cronbach's Alpha. The study examines the behavior of investors relating to their investment performance with respect to fiscal and monetary policy changes covering twenty items structured on five-point Likert scale. To handle this factor analysis is needed to reduce the number of variables which impact on a respondent's investment performance. Thus, the study employs an explanatory factor analysis to explore the common factors that the items of fiscal and monetary policy actions and investment performance of the questionnaire (question 1 to question 20 and question 21 to 23 respectively) belong to. The following criteria of the exploratory factor analysis (EFA) are applied: Factor loadings, KMO, total variance explained, and Eigen value. Here, the factor loadings measure the correlations of each item with the factor to which it belongs. The Kaiser-Meyer Olkin Measure of Sampling Adequacy (KMO) defines the level of suitability in using EFA for the collected data. The total variance explained is applied to discover the number of retained factors in which the last factor represents a small proportion of the explained variance. The Eigenvalue is an attribute of factors which are defined as the amount of variance in all variables explained by a given factor. To achieve the objectives of the study a multiple regression technique was employed.

\section{Results and Discussion}

Factor analysis was employed to discover the factors to which the fiscal and monetary policy variables belong. The Cronbach's Alpha for the four groups, namely, tax policy, money supply, expenditure and investment performance are 0.72 , $0.74,0.61$ and 0.75 respectively, all of which are bigger than the value 0.6 which is the benchmark for marginally acceptable reliability [Gline \& Morgan, 2000]. Further, scale content validity was assessed with the help of two academics, two investor advisors and two high net-worth clients. Accordingly, necessary changes were made to the survey instrument in terms of eliminating, adding/rewording some of the items included in it. Table 1 shows the sample adequacy criteria; the Kaiser-Meyer-Olkin (KMO) value at 0.821 and the Bartlett test value at $978.626(\mathrm{P}<0.00)$. These are found to be satisfactory, thus the factor analysis is appropriate for further analysis.

To determine how many meaningful factors should be retained for interpretation, the Eigen value-one criterion, factor loadings and total variance explained were taken into consideration and three factors were found to be eligible.

Finally, the factors that account for a specified percentage of the data set and the cumulative percentage of variance are treated as equally important for reducing the number of factors. A cumulative percentage of at least $70 \%$ is recommended to retain an adequate number of factors. Varimax rotation together with the Kaiser Criterion was applied to classify and reduce the factors to interpretable components and three factors that are sufficient to explain $70 \%$ of the total data variance qualified (Table 1).

As revealed in table 3 , the variables of monetary policies, tax policies and government expenditure policies are grouped into one related factor each. Three of the four original variables in the government revenue dimension (questions 1, 2 and 3) are retained after the factor analysis while only three of the five original items of monetary policy variables (questions 12, 13 and 14) and three of the four original government expenditure items (questions 
Table 2: Factors and Variance Explained

\begin{tabular}{ccccc}
\hline Serial Number & Factor & Eigen Value & $\begin{array}{c}\text { \% of Variance } \\
\text { Explained }\end{array}$ & $\begin{array}{c}\text { Cumulative } \\
\text { Variance } \%\end{array}$ \\
\hline 1 & Factor 1 & 4.61 & 0.38 & 0.38 \\
2 & Factor 2 & 2.37 & 0.21 & 0.59 \\
3 & Factor 3 & 1.61 & 0.14 & 0.73 \\
\hline
\end{tabular}

Table 3: Factor Analysis for Fiscal and Monetary Policy Variables and Investment Performance

\begin{tabular}{|c|c|c|c|c|c|}
\hline \multirow{2}{*}{ Factors } & \multirow{2}{*}{ Variable } & \multicolumn{4}{|c|}{ Factor Loadings } \\
\hline & & 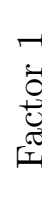 & 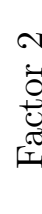 & 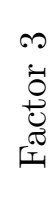 & 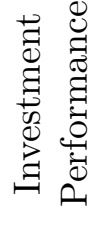 \\
\hline
\end{tabular}

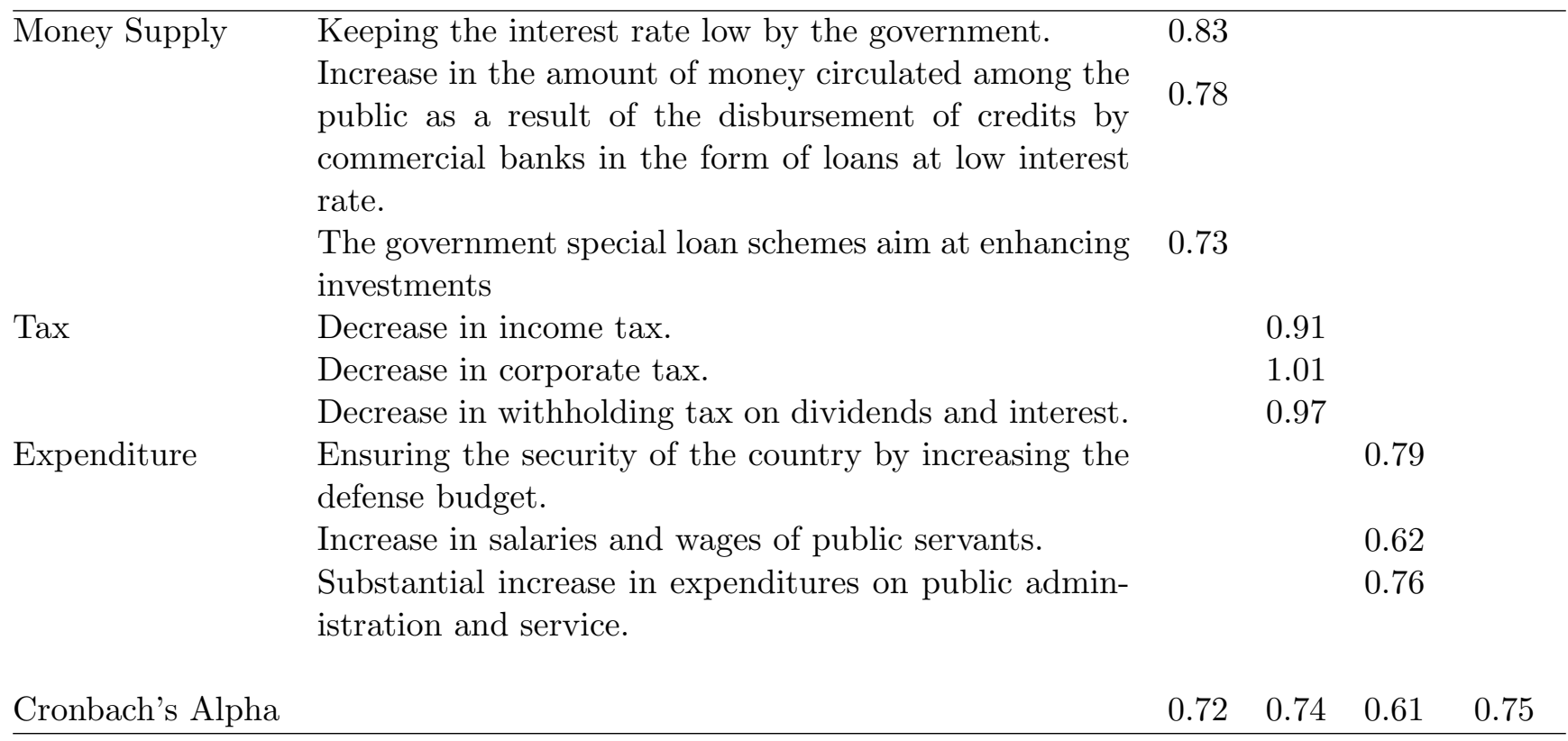

Extraction Method: Principal Component Analysis. Rotation Method: Varimax with Kaiser Normalization.

Source: Survey Data.

6,7 and 8) are accepted by the factor analysis. Factor analysis retained all the three original items of investment performance in one dimension. Thus, the above factor analysis confirms that the government revenue, government expenditure and monetary policy variables influence individual investors performance at the CSE.

The two key macroeconomic policies, monetary and fiscal policies, are designed by the government to achieve objectives such as the desired rate of growth in real activity, controlling the exchange rate, price stability, balance of payment equilibrium and employment. Monetary policy is implemented by the Central Bank to control the availability and cost of credit in the economy and is aimed at changes in the money supply and interest rates. Alternatively, fiscal policy employs policy instruments such as government revenue and government expenditure to influence the aggregate level of economic activity. A change in either fiscal or monetary policy instruments leads to a change in interest rates instantaneously, hence investors respond quickly by changing their portfolios based on the intrinsic value of stocks. Accordingly, contractionary, or expansionary fiscal and monetary policies would have a positive or negative effect on the stock returns of individual investors. The investment performance which the 
Table 4: Statistics of the Fitted Multiple Regression

\begin{tabular}{|c|c|c|}
\hline $\begin{array}{c}\text { Fiscal and Monetary } \\
\text { Policy Variable }\end{array}$ & Coefficient & P Value \\
\hline Constant & 3.317 & $0.000^{* *}$ \\
\hline $\begin{array}{lr}\text { Perceptions } & \text { towards } \\
\text { expansionary } & \text { Monetary } \\
\text { Policy } & \end{array}$ & 0.332 & $0.000^{* *}$ \\
\hline $\operatorname{Tax}$ & -0.145 & $0.060^{*}$ \\
\hline $\begin{array}{l}\text { Expenditure } \\
\text { R-Sq. }=16.9 \%\end{array}$ & 0.268 & $0.001^{* *}$ \\
\hline
\end{tabular}

Note: ${ }^{* *}$ and $*$ indicate significance at $99 \%$ and $90 \%$ respectively.

investors expect depends on how they perceive the changes in fiscal and monetary policies (change in government tax policies, expenditure, money circulation among the public and interest rates). The explanatory factor analysis extracted nine variables under three fiscal and monetary policy dimensions. The results of the multiple regression analysis are presented in table 4 .

Government fiscal policy affects investors' investment performance through an increase in government expenditure which will lead to an increase in the income of the household that transmits to increased consumption and affects the stock market positively. The Keynesian total expenditure model explains that the government spending stimulates expansion in business output and provides short term stimulus to help halt a recession or depression. Government expenditure affects the development of the stock market through its effect on the decisions and activities of the private sector firms and households [Frenkel \& Razin, 1987]. Businesses enjoy high government patronage which could result in enhanced profitability and inspiring dividends for shareholders, and hence, drive stock prices up thereby ensuring constant returns.

Table 4 shows that government expenditure impacts positively on investor performance. This reveals that increased government expenditure as measured by the rapid development of infrastructure facilities, an increase in the defense budget, a substantial increase in expenditure on public administration and service, and an increase in salaries and wages of public servants directly impacts on individual investors' investment performance in the CSE. The government's decisions to facilitate more and more infrastructure and a better public service encourages businesses and boost the profits of firms, thereby attracting investors via impressive dividends. Increased defense expenditure ensures a country's security by providing an investorfriendly environment that attracts both local and foreign investors. Likewise, businesses enjoy higher profits that lead to more dividends thus increasing the prices of stocks. On the other hand, government expenditure influences the stock market through its effect on the income of government employees. Investors may invest a part of their income in stocks with an expectation of higher returns by evaluating returns on stocks and returns on alternative investments and hence stock prices go up. An expansionary fiscal policy, that is, government actions to increase both recurrent and capital expenditure, and to boost production (GDP) can have an impact on increases in aggregate demand thereby ensuring higher dividends through enhanced profits for firms. Thus, investors might assume that expansionary fiscal policy is a signal of increases in future returns.

This finding is consistent with the predictions of the Keynesian model, which states that an increase in government expenditure leads to higher economic growth that boosts domestic output and fuels the growth of the economy, thereby potentially increasing stock prices. However, this contradicts the Ricardian view that suggests that fiscal policy can have no impact on aggregate demand as any public borrowing will be offset by the private savings of rational households. Our finding also does not support the classical economic theory that argues the crowding out effects of fiscal policy in the market for loanable funds and of the productive sectors of the economy. Thus, fiscal policy could drive stock prices lower through the crowding out of private sector activity. This finding is contradictory with the stated findings of Ardagna (2009) that fiscal adjustments based on expenditure reductions are related to an increase in stock market prices, and those of Afonso \& Sousa (2011) who report that government expenditure shocks have a negative effect on stock prices and government revenue shocks have little positive effects on stock prices.

Government fiscal policy actions, that is, changes in taxes which result in budget deficits or surpluses also play an important role in the determination of stock prices, and rational 
investors employ portfolio diversification strategies based on such policy changes. Increases in taxes would lower stock prices since they discourage investors from investing in the stock market if government expenditure is unchanged. On the other hand, increases in government borrowing to finance large budget deficits raises interest rates, thereby lowering stock prices.

The results also show that all the taxes in one dimension have significant negative effects on individual investors expected returns. In the context of corporate tax, a reduction in the tax rate results in larger profits to investors that can be distributed as dividends, and hence, increase returns. Alternatively, when faced with decreased corporate tax obligations, a firm is to some extent able to enjoy the positive effects on its equity return by switching to equity financing without having a corresponding increase in the interest rate, thus confirming a negative effect.

The findings indicate that income taxes and withholding taxes (direct taxes) have a larger effect on investors expected stock returns as they directly affect household disposable income. Decreased income tax and withholding tax rate imply higher disposable household income which enables people to invest more in stocks and that, in turn, yields higher returns. Thus, the results confirm the negative effect of taxes on investment performance of individual investors in the CSE. This finding suggests that budget deficits do matter in rational investment decisions by the investors and implies a violation of the Ricardian Equivalence Proposition, which states that the current government deficits become irrelevant for current portfolio substitution decisions by rational investors if they correctly anticipate increased future taxation. Laopodis (2006) proposes that an increase in tax receipts by the government implies lower government borrowing and thus a lower interest rate. On the other hand, stock market declines mean lower corporate profits and lower tax revenues, and this might necessitate higher government borrowing which would place an upward pressure on interest rates. The findings strongly confirm this view which also assumes a violation of the Ricardian Equivalence Proposition yet again.

Arin et al. (2009) suggest that taxes not only have a very real impact on output growth, but also affect stock market returns in various ways, and that financial markets are a transmission channel for fiscal shocks where the effects of fiscal policy on stock market returns depends on the type of fiscal instrument used. By considering various components of tax policy they find that not all taxes depress stock returns, both indirect and labour taxes have significant negative effects on excess market returns. Our finding greatly supports their view of the negative effect of indirect and labour taxes on excess market returns. Further, our findings do not support their suggestion that corporate tax innovations do not have any statistically significant effect on stock returns.

Monetary policy (changes in money supply and interest rates) is generally designed to persuade the availability, quantity and direction of money and credits to attain a sustainable development of the economy and transmit this impact to the stock market through various channels. The monetary policy variables (expansionary monetary policy) influence the investment decisions of investors significantly and these include keeping the interest rate low by the government, increasing the amount of money circulated among the public as a result of disbursement of credits by commercial banks in the form of loans at low interest rates and launching government special loan schemes aimed at enhancing investment.

The results of the table 4 demonstrate that expansive monetary policy impacts positively on individual investor performance. This implies that an expansive monetary environment, an increase in money supply and a low interest rate, are commonly viewed as good news for investors as these increase economic activity and higher earnings for firms. Thus, stock market participants give close attention to strategies based on the government's stance on monetary policy and they may undertake portfolio diversification strategies. ${ }^{1} \mathrm{An}$ increase in money circulation among the general public enhances the supply of funds in the stock market with an expectation of higher dividends. Investors believe that they will demand more stocks if they have more disposable income, as the additional money can be invested in financial assets such as common stocks. In addition, interest rate is one of the most important and sensitive factors that affect investor decisions and determine

\footnotetext{
${ }^{1}$ Jensen et al. (1996) suggest that monetary environment affects investors' required returns. See also Fama \& French (1989), Jensen et al. (1996), and Booth \& Booth (1997).
} 
the trend of the stock market. Low interest rates encourage higher capital flows to the stock market in the expectation of a higher rate of return as a change of interest rate causes a substitution effect in investment portfolios that can affect the return rate of financial assets. The investors' choice between stocks and other financial assets is determined by the interest rate. This affects the supply of funds in the stock market as a low interest rate lowers the intrinsic value of the stocks shifting from other investment alternatives to common stocks. Moreover, low interest rates facilitate easy and cheap credit to firms resulting in low borrowing costs and higher profits, hence increased returns to investors. Easier monetary policy raises stock prices, lowers risk premiums, and in turn higher stock prices increase the wealth of households, inducing consumers to spend more ${ }^{2}$. Furthermore, high stock prices in fact reduce the cost of capital for firms, stimulating increased capital investment which tends to stimulate the economy. This reveals that stock market participants seem to be highly responsive to government monetary policy actions. Thus, in the light of the above theoretical explanation, we strongly confirm the positive association between expansionary monetary policy and individual investor performance.

This finding greatly supports those of Conover et al. (1999), Ehrmann \& Fratzscher (2004), Rigobon \& Sack (2003) and Sousa (2010), who report a strong positive relationship between expansionary monetary policy and stock market returns. This is also in line with Okpara (2010), Thorbecke \& Lee (1995) and Akinkuotu (2013) who suggest that monetary policy has a significant effect on stock returns. Francesco (2008) argues that expansive monetary policy may influence stock market returns much more than restrictive monetary policy while Okpara (2010) investigates the effect of monetary policy on the stock market returns in Nigeria and finds that the monetary policy is a significant determinant of long run stock market returns in which the high Treasury bill rate $^{3}$ reduces stock market returns, and our

\footnotetext{
${ }^{2}$ Conversely, restrictive monetary policy is associated with lower stock prices given the higher discount rate for the expected stream of cash flows and/or lower future economic activity. Fair (2002) shows that one-third of the changes in equity prices are associated with news on monetary policy.

${ }^{3}$ Bernanke \& Kuttner (2005) find that a surprise increase in the policy rate decreases stock prices in three ways: (i) decreasing expected future dividends, (ii) increasing the
}

findings strongly support their views. Thus, the results of the regression analysis show that the positive impact of monetary policy instruments on individual investor performance furnishes ample evidence for investors to increase their investment in the stock market. When a Central Bank tends to reduce their policy rates, investors should increase their buy and hold strategies ${ }^{4}$.

\section{Conclusion}

The effect of fiscal and monetary policy is transmitted in several ways in investor choice and in the performance of investments. Individual investors are highly responsive to news on fiscal and monetary policy actions and they tend to often make portfolio readjustment strategies. More importantly, we found evidence that the interaction between the two policies plays a key role in determining the stock returns expected by individual investors in the CSE. Specifically, the individual stances on fiscal and monetary policy, whether expansionary or contractionary, through government expenditure, taxes, money supply and interest rates as well as their interaction, directly affect the investment performance of individual investors. The empirical results show that a government's choice of tax instrument has a significant influence on stock returns and all taxes jointly depress investors' investment performance. Government expenditure as a fiscal policy variable has a positive impact on investment performance, which implies that a continual increase in government expenditure might lead to the enhancement of firms' profits and returns to investors, causing stock prices to go up. A decrease in interest rates is highly sensitive public information and together with an increase in money circulation among the public under the monetary policy dimension impacts positively on investors' investment performance. This is as expected, as an increase in money circulation in the economy would prompt investors to make investments since extra funds are available. Further, as theory explains, a decrease in interest rates increases the value of stock prices in the basic stock valuation model and persuades investors to make buy decisions, hence funds flow to the stock market from less profitable

future risk-free rate, and (iii) increasing the equity premium required to hold equities.

${ }^{4}$ In contrast, higher interest rates depress stock prices as investors shift from common stocks to other profitable investments such as Treasury bills and corporate bonds. 
investments. Thus, the overall results reveal that investors in the CSE are highly responsive to information on fiscal and monetary policies.

These results have important implications for both investors and stock market analysts in their effort to understand the impact of fiscal and monetary policies on the stock return expectations of individual investors. Also, they should consider both fiscal and monetary policy decisions and their interactions together rather than in isolation. The Government should be aware of how fiscal and monetary variables influence stock market performance and how investors react to such policy changes and act accordingly to achieve higher economic growth and stock market development by attracting both local and foreign investors with an improved investor friendly environment.

\section{References}

Afonso, A., \& Sousa, R.M. (2011). What are the effects of fiscal policy on asset markets? Economic Modelling, 28, 18711890. DOI: 10.1016/j.econmod.2011.03.018

Agnello, A., \& Sousa, R. M. (2011). Can fiscal stimulus boost economic recovery? Revue conomique, 62(6), 1045-1066 DOI: $10.3917 /$ reco.626.1045

Akinkuotu, O. K. (2013). Comparative impact of fiscal and monetary shocks on stock market performance in Nigeria, Retrieved from http://aercafricaevents.org/papers/GroupC/ CPPC3-Akinkuotu\%20Yemisi.pdf.

Ardagna, S. (2009). Financial markets' behaviour around episodes of large changes in the fiscal stance. European Economic Review, 53, 3755. DOI: $10.1016 /$ j.euroecorev.2008.07.003

Arin K.P., Mamun A., \& Purushothman N. (2009). The effects of tax policy on financial markets: G3 evidence. Review of Financial Economics, 18, 3346. DOI: 10.1016/j.rfe.2008.05.001

Bernanke, B.S., \& Kuttner, K. N. (2005). What explains the stock market's reaction to federal reserve policy? The Journal of Finance, 60, 1221-1257. DOI: 10.1111/j.15406261.2005.00760.x
Bjornland, H.C. \& K. Leitemo. (2009). Identifying the interdependence between US monetary policy and the stock market. Journal of Monetary Economics 56: 275-282 DOI: 10.1016/j.jmoneco.2008.12.001

Bjornland, H.C., \& Jacobsen, D. H. (2008). The role of house prices in the monetary transmission mechanism in the U.S. Norges Bank, Working Paper No. 2008/24.

Blanchard, O.J. (1981). Output, the stock market and interest rates. American Economic Review, $71,132-43$.

Bomfim, A. (2003). Pre-announcement effects, news effects and volatility. Journal of Banking \& Finance, 27, 133-151. DOI: 10.1016/s03784266(01)00211-4

Booth, J.R. \& Booth, L.C. (1997). Economic factors, monetary policy and expected returns on stocks and bonds. Economic Review Federal Reserve Bank of San Francisco 2, 3242. DOI: 10.4324/9780429270949-61

Bredin, D., Hyde, S., Nitzsche, D., \& O'Reilly, G. (2007). UK stock returns and the impact of domestic monetary policy shocks. Journal of Business Finance and Accounting, 34, 872-888. DOI: $10.1111 /$ j.1468-5957.2006.02001.x

Castelnuovo, E. \& Nisticò, S. (2010). Stock market conditions and monetary policy in a DSGE model for the U.S. Journal of Economic Dynamics and Control, 34: 1700-1731. DOI: 10.1016/j.jedc.2010.06.028

Chatziantoniou, I., Duffy, D., \& Filis, G. (2013). Stock market responses to monetary and fiscal policy shocks: multi-country evidence. Economic Modeling, 30, 764769. DOI: 10.1016/j.econmod.2012.10.005

Conover, C. M., Jensen, G. R. Johnson, R. R., \& Mercer, J.M. (1999). Monetary environments and international stock returns. Journal of Banking and Finance, 23, 1357-1381. DOI: 10.1016/s0378-4266(99)00007-2

Darrat, A. (1988). On fiscal policy and the stock market. Journal of Money Credit and Banking, 20, 353-363. DOI: $10.2307 / 1992261$ 
Ehrmann, M., \& Fratzscher, M. (2004). Taking stock: monetary policy transmission to equity markets. Journal of Money, Credit and Banking, 36(4), 719-737. DOI: 10.1353/mcb.2004.0063

Fair, R. (2002). The events that shook the market. Journal of Business, 75(4), 713731. DOI: $10.1086 / 341640$.

Fama, E.F., \& French, K. R. (1989). Business conditions and expected returns on stocks and bonds. Journal of Financial Economics, 25, 2349. DOI: $10.1016 / 0304-405 x(89) 90095-0$

Francesco, G. (2008). European central bank and federal reserve USA: monetary policy effects on the returns volatility of the Italian Stock Market Index Mibtel.

Frenkel, J. A. \& Razin, A. (1987). Fiscal Policies and the World Economy: An Intertemporal Approach. $1^{\text {st }}$ ed., Cambridge: MA, MIT Press.

Gali, J., \& Gertler, M. (2007). Macroeconomic modeling for monetary policy evaluation. Journal of Economic Perspectives, 21, 25-45. DOI: $10.1257 /$ jep.21.4.25

Gliner, J. A., \& Morgan, G.A. (2000). Research methods in applied settings: an integrated approach to design \& analysis. Morwah, NJ: Lawrence Erlbaum.

G'ond'or M., \& Bresfelean, V. P. (2011). Fiscal policy, the main tool to influence the capital markets' strength, Recent Advances in Applied \& Biomedical Informatics and Computational Engineering in Systems Applications, 458-463.

Goodness C. A., Mehmet B., Rangan G., Charl J., Stephen M., M., \& Zeynel A. O. (2012). Fiscal policy shocks and the dynamics of asset prices: the south african experience, Retrieved from http://repository.up.ac.za/bitstream/handle/ 2263/41106/Aye_Fiscal_2014.pdf?sequence=1.

Gregoriou, A., Kontonikas, A., MacDonald, R., \& Montagnoli, A. (2009). Monetary policy shocks and stock returns: evidence from the British market. Financial Markets and Portfolio Management, 23(4), 401-410. DOI: 10.1007/s11408009-0113-2
Jakova, S (2016). Stock market response to fiscal policy shocks: evidence from EU countries from Central and Eastern Europe, Network Intelligence Studies, 4 (2). DOI: 10.6007/ijarafms/v6i2 $/ 2037$

Jansen D.W., Li Q., Wang Z., \& Yang J. (2008). Fiscal policy and asset markets: a semi-parametric analysis. Journal of Econometrics, 147, 141-150. DOI: 10.1016/j.jeconom.2008.09.007

Jensen, G., Mercer, J., \& Johnson, R. (1996). Business conditions, monetary policy and expected security returns. Journal of Financial Economics, 40(2), 213-238. DOI: 10.1016/0304$405 \mathrm{x}(96) 89537-7$

Kurov, A. (2010). Investor sentiment and the stock market's reaction to monetary policy. Journal of Banking and Finance, 34, 139-149. DOI: 10.1016/j.jbankfin.2009.07.010

Kuttner, K.N. (2001). Monetary policy surprises and interest rates: evidence from the feds fund future market. Journal of Monetary Economics, 47, 523-544. DOI: 10.1016/s03043932(01)00055-1

Laopodis, N. T. (2006). Fiscal Policy, Monetary Policy, and the Stock Market, Retrieved from https://www. semanticscholar.org/paper/Fiscal-Policy\%2C-Monetary-Policy-\%2C-and-the-stock/ 2fde5b1acf610f32b83f9906510295f3b8cfd45c? p2df. DOI: 10.1093/oso/9780190076030.003.0021

Laopodis, N. T. (2010). Dynamic linkages between monetary policy and the stock market. Review of Quantitative Finance and Accounting, 35, 271-293. DOI: doi.org/10.1007/s11156009-0154-7

Lawal, A., Somoye, R.O., Babajide, A. A., \& Nwanji, T.I. (2018). The effect of fiscal and monetary policies interaction on stock market performance: Evidence from Nigeria. Future Business Journal, 4 (2018), 16-33. DOI: 10.1016/j.fbj.2017.11.004

Melitz, J. (1997). Some cross-country evidence about debt, deficits and the behaviour of monetary and fiscal authorities. CEPR discussion paper, No. 1653, CEPR, London. 
Melitz, J. (2000). Some cross-country evidence about fiscal policy behaviour and consequences for EMU. European Economy Reports and Studies 2: 3-21. 23

Mishkin, F.S. (2001). The transmission mechanism and the role of asset prices in monetary policy. National Bureau of Economic Research, Working Paper 8617. DOI: 10.3386/w8617

Muscatelli, V. A., \& Tirreli, P. (2005). Analyzing the interaction of monetary and fiscal policy: does fiscal policy play a valuable role in stabilisation? CESifo Institute for Economic Research, 51, 549585. DOI: 10.1093/cesifo/51.4.549

Muyanga, C. (2014). The effect of fiscal policy on the performance of the Nairobi securities exchange A Research Project Submitted in partial fulfilment of the requirements for award of the Degree of Master of Business Administration, University of Nairobi.

Naik, P. K. (2013). Does Stock Market Respond to Economic Fundamentals? Time Series Analysis from Indian Data. Journal of Applied Economic and Business Research, 3(1), 34-50.

Nwaogwugwu, I. C., (2018). The Effects of Monetary and Fiscal Policy on the Stock Market in Nigeria, Journal of Economics and Development Studies, 6 (1), 79-85

Okpara G. C. (2010). Monetary policy and stock market returns: evidence from Nigeria, Journal of Economics, 1 (1), 13-21 DOI: $10.1080 / 09765239.2010 .11884920$

Osamuonyi, I. O., \& Evbayiro-Osagie, I. (2012). The Relationship between Macroeconomic Variables and Stock Market Index in Nigeria. Journal of Economics, 3(1), 55-63. DOI: 10.1080/09765239.2012.11884953

Poole, W., \& Rasche, R. H. (2000). Perfecting the market's knowledge of monetary policy. Journal of Financial Services Research, 18, 255-298. DOI: $10.20955 /$ wp. 2000.010
Rigobon, R., \& Sack, S. (2003). Measuring the response of monetary policy to the stock market. Quarterly Journal of Economics, 118, 639-669. DOI: 10.1162/003355303321675473

Sargent, T., \& Wallace, N. (1981). Some unpleasant monetarist arithmetic. Federal Reserve Bank of Minneapolis Quarterly Review Fall: 117. DOI: $10.21034 / q r .531$

Shah, A. (1984). Crowding out, capital accumulation, the stock market, and money-financed fiscal policy. Journal of Money, Credit, and Banking, 16: 461473. DOI: 10.2307/1992184

Sousa, R.M. (2010). Housing wealth, financial wealth, money demand and policy rule: Evidence from the Euro area. The North American Journal of Economics and Finance, 21, 88-105. DOI: 10.1016/j.najef.2009.11.006

Tavares, J. \& Valkanov, R. (2003). Fiscal policy and asset returns. Department of economics Universidade Nova, Lisbon.

Thorbecke, W., \& Lee, C. (1995). Monetary policy stock returns, and the role of credit in the transmission of monetary policy. Levy Economics institute working paper No.133. DOI: $10.2139 /$ ssrn. 84408

Tobin, J. (1969). A general equilibrium approach to monetary theory. Journal of Money, Credit, and Banking, 1(1), 1529. DOI: 10.2307/1991374

Trebicka, B. (2015). Does fiscal policy matters for economic growth? Empirical study of Albanian situation. Interdisciplinary Journal of Research and Development. II (2).

Van Aarle, B., Garretsen, H., \& Gobbin, N. (2003). Monetary and fiscal policy transmission in the Euro-area: evidence from a structural VAR analysis. Journal of Economics and Business, 55(5-6), 609-638. DOI: 10.1016/s01486195(03)00056-0

Zoli, E. (2005). How does fiscal policy affect monetary policy in emerging market countries? Bank of International Settlements, Working Papers No. 174. DOI: 10.2139/ssrn.757632 